\title{
Postharvest Management and Value Addition of Ginger (Zingiber Officinale Roscoe): A Review
}

\author{
Manisha Kaushal ${ }^{1}$, Anil Gupta ${ }^{1 *}$, Devina Vaidya ${ }^{1}$, Meenu Gupta ${ }^{2}$
}

\author{
${ }^{1}$ Department of Food Science and Technology, Dr YS Parmar University of Horticulture and Forestry, Nauni, Solan-173230, \\ India. \\ ${ }^{2}$ Department of Vegetable Science, Dr YS Parmar University of Horticulture and Forestry, Nauni, Solan-173230, India.
}

\begin{abstract}
Ginger is an important spice crop and India is one of the leading producer and exporter of ginger in the world. Ginger is widely used around the world in food as a spice both in fresh and dried form which adds flavour to the meal by creating spicy pungent taste. The chemical components of the ginger rhizome vary considerably depending on the location of cultivation and postharvest treatments. Ginger contains polyphenol compounds such as gingerol and its derivatives like zingiberone, bisabolene, camphene, geranial, linalool, borneol and oleoresin (combination of volatile oils and resin) that accounts for its characteristic aroma and therapeutic properties. Fresh ginger are perishable in nature and are spoiled due to improper handling, growth of spoilage microorganisms, susceptibility to rhizome rot, wilting and sprouting, action of naturally occurring enzymes, chemical reactions and structural changes during storage. Keeping in mind the low shelf-life of fresh ginger and inadequate facility for their modern storage leading to distress sale, value addition could be a viable alternative which will fetch remunerative price to the growers. The present scenario, nutritional importance, postharvest management, value added products of ginger have been discussed in detail in the review.
\end{abstract}

Keywords - Ginger, novel products, scenario, appetized flakes, bars, salted ginger, crystallized ginger, quality, storage, value added products.

\section{INTRODUCTION}

Ginger originated from India from where it was introduced to Africa and Caribbean, however no definite information on the primary centre of domestication of ginger is available (Prabhakaran, 2013). It is now cultivated throughout the humid tropics (Meadows, 1998) and is a most widely used spice worldwide. Ginger is a monocotyledonous perennial herb with robust, heavily branched rhizomes called hands or laces. India is the largest producer of ginger and the annual production is around 2, 63,170 tonnes from an area of about 77,610 hectares, contributing approximately 30 to $40 \%$ of the world production (Ravindran and Nirmal, 2005).
Ginger is a medicinal plant that has been widely used all over the world, since antiquity, for a wide array of unrelated ailments including arthritis, cramps, rheumatism, sprains, sore throats, muscular aches, pains, constipation, vomiting, hypertension, indigestion, dementia, fever and infectious diseases (Ali et al. 2008). Ginger has direct anti-microbial activity and thus can be used in treatment of bacterial infections (Tan \& Vanitha, 2004). Ginger belongs to Zingiberaceae family and an English botanist William Roscoe (1753-1831) gave this plant the name Zingiber officinale in the year 1807. The name of the genus Zingiber derives from a Sanskrit word denoting "horn shaped" in reference to the protusions on the rhizomes (Ghosh et al, 2011). It is an oldest rhizome widely domesticated as a spice where the edible part is the swollen underground stem or rhizome. The Zingiberaceous plants have strong aromatic and medicinal properties and are characterized by their tuberous or non-tuberous rhizomes (Chen et al. 2008).

Ginger is valued as a spice because of its aroma and pungency (Paull et al. 1988) and has been used through ages in almost all systems of medicine against many maladies due to its medicinal properties (Kubra and Rao 2012). Despite of its use as flavoring agent, ginger is also appreciated in ayurvedic, tibbe-e-unani (Srivastava and Mustafa 1989), allopathic (Fessenden et al. 2001), aromapethy (Shelly et al. 2004) and household medicines (Sloand and Vessey 2001). Ginger rhizome can be employed in the form of fresh paste, ginger tea (flavoring), dried powder and preserved slices (El-Ghorab et al., 2010). Ginger can be utilized in different commercial products like cookies, candy, teas, tinctures, sodas, jam, beer, capsule and syrup (Maxwell, 2008). Ginger bread, confectionery, ginger ale, curry powders, certain curried meats, table sauces, in pickling and in the manufacture of certain soft drinks like cordials, ginger cocktail, carbonated drinks, etc are some of the value added products of ginger. Ginger is also used for the extraction of ginger oil, oleoresin, essences, tinctures etc (Pruthi, 1998). 


\section{PRODUCTION AND CONSUMPTION}

The ginger is an erect perennial growing plant from one to three feet in height, consisting of thick scaly rhizomes (underground stems) which branch with thick thumb like protrusions, known as "hands". The rhizomes are 7-15 cm long and $1-1.5 \mathrm{~cm}$ broad and laterally compressed depending on cultivars and growing conditions (Awang 1992; Bisset and Wichtl 1994). The outer surface is buff coloured and longitudinally striated or fibrous in nature (Ghosh et al, 2011). Ginger is commercially cultivated in India, China, South East Asia, West Indies, Mexico and other parts of the world. Most promising cultivars of ginger are Nadia, Maran, China, Ernad, Suprabha, Suruchi, Surabi, Varad, Himgiri etc. The variety IISR Varada is suited for fresh ginger, dry ginger and making candy while, IISR Rejatha is rich in essential oil.

The world production of ginger is 20,95,056 tonnes from an area of 3,22,157 hectares, while India's share is 7,03,000 tonnes from an area of 1,50,000 hectares (FAO, 2014). It is difficult to compare import data because they usually do not distinguish fresh from dried ginger. For instance, Japan is the number one importer and consumer of ginger with 1 , 04,379 $\mathrm{t}$ in the year 2002 (ITC, 2002), but Japanese traditionally consume preserve ginger made from a mild fresh rhizome (Govindarajan 1982). Other major importing countries are: US (19,035 t), UK (10,337 t), Saudi Arabia $(8,248 \mathrm{t})$, Singapore (import 7,566 t, re-export 2,989 t), Malaysia (import 7,652 t, re-export 1,334 t), Korea $(6,805$ t), the Netherlands (import 6,981 t, re-export 2,858 t), Canada (4,680 t), Germany, and France. Within the last decade China has become a major competitor overtaking some traditional exporting countries.

\section{Traditional use}

Zingiber officinalis is one of these traditional folk medicinal plants that have been used for over 2000 years by Polynesians for treating diabetes, high blood pressure, cancer, fitness and many other illnesses (Tepe et al., 2006). Zingiber officinalis contains a number of antioxidants such as beta-carotene, ascorbic acid, terpenoids, alkaloids, and polyphenols such as flavonoids, flavones glycosides, rutin, etc. (Aruoma et al., 1997). Ginger has been used as a spice and as natural additives for more than 2000 years (Bartley and Jacobs, 2000). Also, ginger has many medicinal properties. Studies have shown that, the long term dietary intake of ginger has hypoglycaemic and hypolipidaemic effect (Ahmed and Sharma, 1997). In traditional Chinese and Indian medicine, ginger has been used to treat a wide range of ailments including stomach aches, diarrhea, nausea, asthma, respiratory disorders (Grzanna et al., 2005). Medicinal Properties
Ginger has been identified as an herbal medicinal product with pharmacological effect. It is known as Sunthi in ayurveda and description of the plant appears in the old text like Charaka, Sushruta, Vagbhatta and Chakra-dutta. Pharmacologically, the drug in ayurveda medicinal part of the herb is dried and is described as appetizer. Ginger has been used as a traditional medicine to treat stomach disorders, nausea, diarrhea, colic, arthritis, heart conditions, menstrual period, dyspepsia, rheumatism and flu like symptoms, bronchitis and many more (Gosh et al. 2011, Latona et al, 2012, Grzanna et al, 2005). It is extensively used around the world in foods as a spice and highly value in the international market for its aroma, pungency and high oleoresin content (Onwuka et al. 2002). It is used as a flavouring agent in foods and beverages and as a fragrance in soaps and cosmetics (Alam 2013). Ginger is thought to act directly on the gastrointestinal system to reduce nausea. Therefore, it is used to prevent nausea resulting from chemotherapy, motion sickness, and surgery. It is known as a popular remedy for nausea during pregnancy (Langner $e t$ al. 1998). Ginger is also used to treat morning sickness, colic, upset stomach, gas, bloating, heartburn, flatulence, diarrhea, loss of appetite and dyspepsia (discomfort after eating) and is recommended to enhance the digestion of food (Ali et al. 2008). Because of its warming effect, ginger acts as antiviral for treatment of cold and flu (Qidwai et al. 2003).

\section{Mechanism of action of ginger}

The rhizome of the Zingiber officinale plays an important role in prevention of diseases, but the exact mechanism of action in diseases management is not understood fully. It is thought that ginger act as anticancer due to various constituents such as vallinoids viz; 6-gingerol and 6paradol, shogaols, zingerone, and galanals $\mathrm{A}$ and $\mathrm{B}$ (Aggarwal and Shishodia 2006; Miyoshi et al. 2003; Shukla and Singh 2007) and constituents show a therapeutics role in diseases control via modulation of various biological activities, describe as following:

1. Ginger and its constituents show antioxidant activity and prevent the damage of macro-molecules, caused by the free radicals/oxidative stress.

2. It also shows a vital role as anti-inflammatory processes. Earlier studies on In-vitro investigations of ginger preparations and some isolated gingerol-related compounds showed that anti-inflammatory effects of ginger such as inhibition of COX (Tjendraputra et al. 2001) and inhibition of nuclear factor $\mathrm{\kappa B}$ (Grzanna et al. 2005).

3. Ginger also acts as antitumor via modulation of genetic pathways such as activation tumour suppressor 
gene, modulation of apoptosis and inhibition of VEGF. Earlier study has shown that terpenoids, constituents of ginger induce apoptosis in endometrial cancer cells through the activation of p53 (Liu et al. 2012).

4. Ginger also shows antimicrobial and other biological activities due to gingerol and paradol, shogaols and zingerone. An important finding showed that $10 \%$ ethanolic ginger extract was found to possess antimicrobial potential against pathogens (Giriraju and Yunus 2013).

5. Antioxidants are substances that play a role in the neutralization of free radicals and oxidative.

Chemistry and chemical structure of active constituents

Numerous active ingredients are present in ginger including terpenes and oleoresin which called ginger oil. Ginger also constitutes volatile oils approximately $1 \%$ to $3 \%$ and nonvolatile pungent components oleoresin (Zick et al. 2008). The major identified components from terpene are sesquiterpene hydrocarbons and phenolic compounds which are gingerol and shogaol (Hasan et al. 2012) and lipophilic rhizome extracts, yielded potentially active gingerols, which can be converted to shogaols, zingerone, and paradol. The chemical analysis of ginger shows that ginger contains over 400 different compounds and the major constituents in ginger rhizomes are carbohydrates (50-70\%), lipids (3$8 \%$ ), terpenes and phenolic compounds (Grzanna et al. 2005). Terpene components of ginger include zingiberene, $\beta$-bisabolene, $\alpha$-farnesene, $\beta$-sesquiphellandrene, and $\alpha$ curcumene, while phenolic compounds include gingerol, paradols, and shogaol. The characteristic odour and flavour of ginger are due to a mixture of volatile oils like gingerols (23-25\%) and shogaol (18-25\%) and these constituents are found in higher quantity as compare to others. Besides these, amino acids, raw fiber, ash, protein, phytosterols, vitamins (e.g., nicotinic acid, vitamin A) and minerals are also present (Langner et al. 1998; Shukla and Singh 2007). The aromatic constituents include zingiberene and bisabolene. Other gingerol- or shogaol-related compounds (1-10\%), which have been reported in ginger rhizome, include 6-paradol, 1-dehydrogingerdione, 6- gingerdione and 10-gingerdione, 4- gingerdiol, 6-gingerdiol, 8gingerdiol, and 10-gingerdiol, and diaryl-heptanoids (Michiein et al. 2009, Elaissi et al. 2011, Hossain et al. 2011). The mode of action and active constituents present in ginger are listed in Table 1.

Antimicrobial property: Ginger is reported to have antibacterial effect especially against the Staphylococci species and also exhibits antifungal activity against a wide variety of fungi including Candida albicans (Ficker et al. 2003), though Penicillium brevicompactum actually grows on ginger causing rot during post-harvest storage (Overy and Frisvad 2005). According to Islam et al. (2014), the antimicrobial activity of the ginger was found highest against Salmonella spp. while lowest activity was found against Escherichia coli. Staphylococcus aureus showed lower sensitivity to ginger extract as compare to the most other Gram-negative bacteria.

The chemical structures of some of the constituents present in ginger are given in Figure 1.
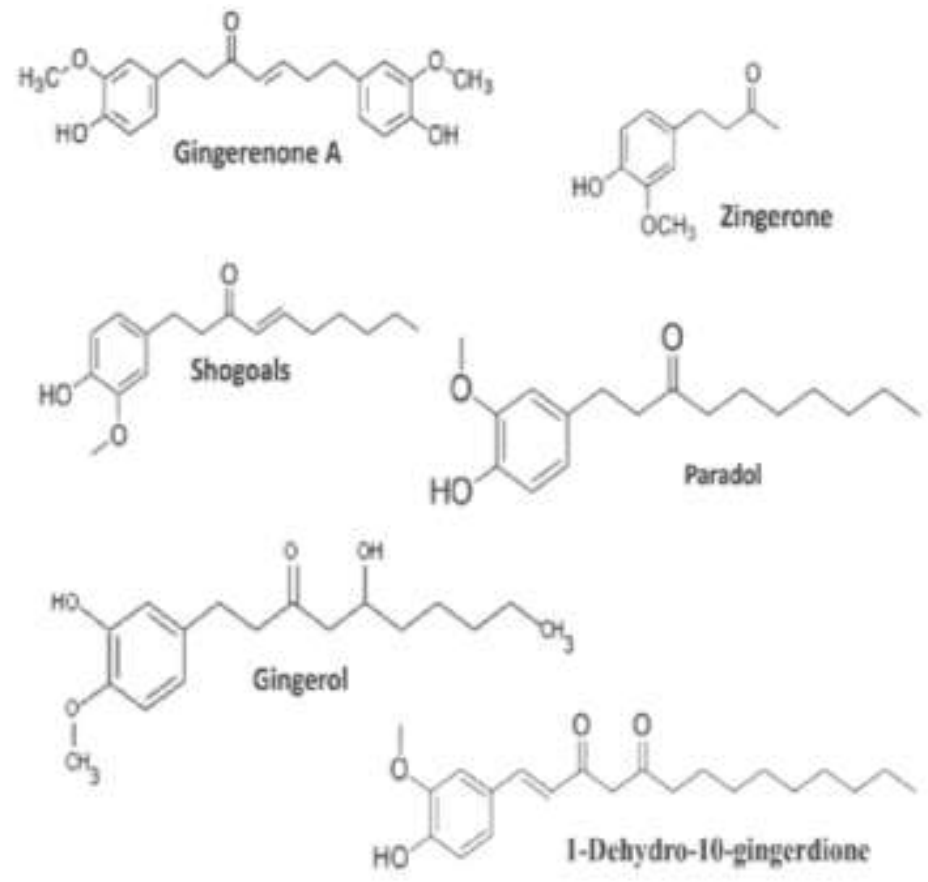

Fig.1: Chemical structure of active ingredients present in ginger. 
Quality characteristics of fresh ginger rhizome

Antioxidant activity: Ginger is a source of a large number of antioxidants and also plays an important role in the reduction of the lipid oxidation and inhibits the pathogenesis of diseases. Ginger extract possesses antioxidative characteristics and shows a role in scavenge superoxide anion and hydroxyl radicals (Cao et al. 1993; Krishnakantha and Lokesh 1993) and gingerol, inhibited ascorbate/ferrous complex induced lipid peroxidation in rat liver microsomes (Reddy and Lokesh 1992). Ginger grown in different parts of the country varies considerably in its intrinsic physical and biochemical properties and its suitability for processing. The important quality parameters of ginger are its fibre, volatile oil and non volatile ether extracts. The research finding reported by different researchers on fresh ginger is detailed in the Table 2.

Ginger oleoresin, a substance having a pungent property is obtained from ground rhizome by extraction with volatile solvents, while the essential oil which lacks pungency is derived from the rhizome by steam distillation. The yield of ginger oleoresin and oil depends upon the cultivar, location, stage of harvesting and method of extraction. Ginger oil is extracted from dried ginger commercially after steam distillation, however fresh ginger can also be used for oil extraction purposes but the yields are quite low (Purseglove et al, 1981). The commercial ginger essential oil is characterized by pale yellow colour, warm, spicy and woody flower with slight lemony notes (Koroch et al, 2007).

\section{Major Post-harvest Problems}

Postharvest Diseases: Postharvest disease in ginger is normally due to rough harvesting and handling practices which result in injury to the skin and flesh of the rhizome (Table 3). Holding ginger at a less than optimal temperature and relative humidity (RH) will accelerate postharvest decay. Postharvest losses from diseases are caused by various microorganisms. Decay can be kept to a minimum by following careful harvesting and handling practices, sanitation of the wash water, curing of the rhizomes after washing to promote wound healing, application of a postharvest fungicide, and holding the rhizomes at $12.5^{\circ} \mathrm{C}$ $\left(55^{\circ} \mathrm{F}\right)$ and 70 to $75 \% \mathrm{RH}$.

\section{Post-harvest Disorders}

Sprouting: Ginger rhizomes will sprout at temperatures above $15.6^{\circ} \mathrm{C}\left(60^{\circ} \mathrm{F}\right)$. Sprouting may begin after several weeks storage at ambient temperature. The rate of sprouting grows as the temperature increases. There is no effective chemical sprout inhibitor for ginger.
Chilling Injury: Physiological disorder that results in pitting and sunken lesions on the rhizome surface, shriveling, softening, flesh darkening, and postharvest decay. Ginger rhizomes are very sensitive to chilling injury or low temperature breakdown if stored below $12^{\circ} \mathrm{C}\left(54^{\circ} \mathrm{F}\right)$.

Shriveling/desiccation: This is a common postharvest disorder of ginger held under low relative humidity (RH) conditions (i.e. less than $65 \% \mathrm{RH}$ ). Shriveling of the rhizome becomes noticeable after the loss of more than $10 \%$ of the initial harvest weight. On the other hand, surface mould will begin to grow at a RH above $90 \%$ and sprouting will be stimulated, especially if the temperature is above $16^{\circ} \mathrm{C}$. In order to minimize weight loss and avoid surface mould, an optimum relative humidity range of 70 to 75 percent is recommended for storing ginger.

\section{Harvesting and Postharvest management}

Maturity Indices: The principal indices used to determine ginger harvest maturity are foliage senescence, age of leaves and rhizome size. Rhizomes do not continue to enlarge and grow without healthy foliage. Delaying harvest until all of the leaves have died is not recommended as it will reduce rhizome quality, increase fiber content, decrease storage life and increase the incidence of sprouting. The drawback of harvesting less mature ginger is that bulbs are susceptible to greater weight loss.

Stage of ginger harvesting for various end uses

\begin{tabular}{|l|l|}
\hline End use & $\begin{array}{l}\text { Stage of harvest } \\
\text { (months after } \\
\text { planting) }\end{array}$ \\
\hline $\begin{array}{l}\text { Vegetable purpose and } \\
\text { preparation of ginger preserve, } \\
\text { candy, soft drinks, pickles and } \\
\text { alcoholic beverages. }\end{array}$ & \\
\hline $\begin{array}{l}\text { Dried ginger and preparation } \\
\text { of ginger oil, oleoresin, } \\
\text { dehydrated and bleached } \\
\text { ginger. }\end{array}$ & \\
\hline
\end{tabular}

Harvest methods: Ginger is almost entirely harvested by hand, although mechanical digging devices are available for use on large-scale planting. The initial step in harvesting is to remove a significant portion of the senescent foliage to make the rhizomes more accessible. Ginger is dug by hand using a fork to loosen the soil around the crown of the plant. The process is done carefully in order to avoid damaging the rhizomes. The rhizomes are gently pulled out of the soil using the remaining length of stem as a handle. Ginger harvested early will still have an actively growing green 
stem attached to the rhizome which needs to be snapped or cut off slightly above the point of attachment to the rhizome. Ginger is then pre-graded in the field for any unmarketable, damaged or diseased rhizome. Harvesting during very wet or very dry conditions is not desirable as this will increase the amount of skinning and make removal of the rhizomes from the soil much more difficult.

Pre-cooling conditions: Forced-air or room cooling to 12 to $14{ }^{\circ} \mathrm{C}\left(54\right.$ to $\left.57^{\circ} \mathrm{F}\right)$ should be used.

Preparation for market: Relatively clean bulbs sold in the domestic market may not require any further cleaning. However, ginger intended for export must be thoroughly cleaned before packing. The ginger intended for long term storage should be washed immediately after harvest and then cured. Ginger should be scrubbed by hand or with a soft-bristled brush in clean water sanitized with $150 \mathrm{ppm}$ hypochlorous acid. Care is required during cleaning to prevent bulb breakage, which increases decay and shrinkage. A fungicide treatment benomyl (500 ppm) or thiabendazole $(1000 \mathrm{ppm})$ can also be applied in the wash tank or as a separate overhead spray application after cleaning.

Remove all damaged and injured bulbs. The remaining marketable bulbs should be sorted according to size and overall appearance. The ginger surface should be clean, bright yellow-brown and appear fresh. It should not be wilted or have any evidence of sprouting. Export quality ginger should be smooth and firm, with uniform shape and size, be free from insect damage and decay, and have a uniform peel colour typical of the variety. The internal flesh should be firm and uniformly cream or pale-yellow coloured, without any indication of darkening.

Curing: Ginger intended for storage should be cured by drying the rhizomes in air at ambient temperature $\left(22^{\circ} \mathrm{C}\right.$ to $26^{\circ} \mathrm{C}$ or $71^{\circ} \mathrm{F}$ to $79^{\circ} \mathrm{F}$ ) and $70 \%$ to $75 \% \mathrm{RH}$ for several days to allow the skin to thicken and the cut surfaces to suberize. Curing will help reducing postharvest weight loss and decay. After curing, the ginger should be kept in wellventilated containers for long-term storage.

Packaging: Ginger of roughly similar size should be packed in each market container. The container should be strong, well ventilated, and capable of being stacked without damaging the bulbs. For the domestic market, wooden crates provide better protection to the ginger than mesh or synthetic sacks. For the export market ginger bulbs should be placed in a clean, strong, well-ventilated fibreboard carton. The surface of the bulbs should be thoroughly dry prior to packing.

Optimum storage conditions: Mature ginger rhizomes can be stored at 12 to $14{ }^{\circ} \mathrm{C}\left(54\right.$ to $57{ }^{\circ} \mathrm{F}$ ) with 85 to $90 \% \mathrm{RH}$ for 60 to 90 days. Storage at $13{ }^{\circ} \mathrm{C}\left(55^{\circ} \mathrm{F}\right)$ with $65 \% \mathrm{RH}$ leads to extensive dehydration and a wilted appearance (Paull and Chen 2015). Holding ginger at ambient temperatures will result in high moisture loss, surface shriveling and sprouting of the rhizome.

\section{Processing and Value addition}

Ginger is used in three forms namely, fresh or green ginger, whole dry ginger and split dry ginger. Fresh ginger are sometimes unsuitable for converting to the dry spice, due to its initial high moisture content causing difficulty in drying and thus a heavy wrinkled product is obtained with low volatile oil content (Balakrishnan, 2005). Fresh ginger suffers from weight loss, shrinkage, sprouting and rotting during storage after 3 to 4 weeks of harvesting. This spoilage can be overcome by processing fresh produce to some value added products (Nath et al, 2013). The various value added products prepared from ginger are ginger oil, oleoresin, ginger candy, ginger preserve, ginger puree, ginger powder, ginger beer and ginger paste (Arya, 2001, Camacho and Brescia, 2009). Ginger is consumed worldwide as flavouring agent which is used extensively in food, beverage and confectionary industries in the products such as marmalade, pickles, chutney, ginger beer, ginger wine, liquors, and other bakery products (wang et al. 2011). In South India, ginger is used in the production of a candy called Injimurappa meaning ginger candy in Tamil (Sebioma et al. 2011). Nath et al, (2013) optimized the protocol for production of instant ginger candy with a slice thickness of 5.0-25.0 mm and blanching time of 10-30 minutes. Further, Siddiqui et al. (2012) standardized the recipe for the preparation of ginger preserve from 70 percent sugar concentration and ginger candy from 75 percent sugar concentration. Similarly, Gupta et al. (2012) also optimized osmo-convective process conditions for preparation of honey ginger candy. Bhuyan and Prasad (1990) evaluated the effect of varied drying temperature $\left(70-90^{\circ} \mathrm{C}\right)$ on the quality of dried ginger and optimized ginger drying at 60 to $70^{\circ} \mathrm{C}$ air temperature.

Further, Jadhav et al, (2012) studied the drying characteristics of ginger (peeled whole, sliced, treated and control) by employing open air sun drying, solar cabinet drying and mechanical tray drying $\left(65^{\circ} \mathrm{C}\right)$ methods and drying time with optimization of mechanical tray drying of peeled untreated sliced ginger. According to Eze and Agbo (2011), solar dried unpeeled ginger contains 7.0\% moisture which was within the standard (6-9\%) acceptable limits as compare to open air dried ginger attaining $17.0 \%$ moisture content. 
Peeling of Ginger: Peeling of ginger is an important step and a prerequisite for preparation of various value added products. After washing the ginger rhizomes are subjected to peeling operation. Indigenously, peeling of ginger is done by scrapping with sharpened bamboo stick. Ginger are irregular in shape and not in a spherical geometry, therefore peeling process is a very tedious, time consuming and labour intensive operation. Commonly used methods of peeling ginger rhizomes include hand peeling, gunny bag peeling, lye peeling and sand blasting (Joshi et al, 1991). Ginger peeling is done manually inspite of machines developed (Agarwal et al, 1987; Ali et al, 1991). Endrais and Asfaw (2011), Eze and Agbo (2011), Yiljep et al. (2005) have reported the adverse effect of peeling.

A mechanical brush type ginger peeling machine has been developed by Rajasthan Agricultural University. The peeling efficiency of the machine was $85 \%$ and the capacity was $200 \mathrm{~kg} / \mathrm{h}$ (Agarwal et al. 1987). Another mechanical ginger peeler was developed with its peeling drum made of diamond cut mesh (Jayashree \& Visvanathan 2013) which has a peeling efficiency of 59\%. Kaushal et al, (2014) evaluated different ginger peeling methods found that maximum recovery of peeled rhizome was obtained by mechanical peeler with peeling losses of 4.51 per cent as compared to other peeling methods like hand peeling, gunny bag peeling, abrasive peeling, lye peeling with a peeling losses of 13.10, 18.0, 11.35 and 28.0 percent respectively.

Ginger Slicing/Splitting: Simonyan et al. (2003) developed a motorized reciprocating ginger slicer consisting of the feeding unit, slicing mechanism and housing. The ginger rhizomes fed manually into the hopper falls by gravity into the cylinder at the bottom of the piston. It is pushed horizontally to the stationary knife blade as the piston moves towards the top dead center. The pushing of the rhizomes forces the ginger through the blade, which are collected at the outlet. Guwo (2008) also developed a ginger splitting machine having stationary cutting blade and two revolving impellers. Constant rotation of the impellers created a synchronized flow of ginger rhizomes inside the splitting chamber. The centrifugal force of the impellers due to their rotation against the stationary knife blade accomplishes the splitting process. Chatthong et al. (2011) similarly designed and built a semi-automatic ginger slicing machine. The machine produce sheet ginger and line ginger.

Polishing: Polishing of dried ginger is done to remove the wrinkles developed during drying process. In the indigenous method the dried ginger is rubbed against a hard surface. However, hand or power operated polishers similar to turmeric polishers are also employed for the purpose of polishing dried ginger. In the case of hand operated polishers an output of 5-6 quintals per day of 8 hours is obtained with the help of two persons. The dried ginger rhizomes are manually graded. The machines of various capacities to pulverize dried ginger from $25 \mathrm{~kg}$ per batch to continuous powdering of $2-3 \mathrm{t} /$ day for large scale production are available.

Dried ginger: Drying of ginger basically involves two stages; peeling the rhizomes to remove the outer skin and sun or mechanical drying to a safe moisture level (Balakrishnan, 2005). For converting to dry ginger the crop is harvested at full maturity. In most growing areas, the scraped ginger is dried in the sun but where unfavourable seasonal conditions prevail, improved drying methods using mechanical or solar dryers are also used. In mechanical dryers, $57.2^{\circ} \mathrm{C}$ is reported to be the highest temperature at which ginger for the spice market could be dehydrated (Ravindran and Nirmal, 2005). Singh et al, 2008 studied the fluidized bed drying of ginger flakes where the ginger were manually cleaned, steeped in portable water for 2 hours followed by soaking in calcium oxide solution $(1 \%, 2 \%$ and $2.5 \%)$ for 6 hours.

The quality of dried ginger depends on appearance, pungent principles, fibre, aroma and flavor characteristic of volatile oil (Ebewele and Jimoh 1988). Alakali and Satimehin (2009) studied drying kinetics of ginger slices at varying temperature of $40,45,50$ and $55^{\circ} \mathrm{C}$ and found that the drying proceeded faster at high temperatures; while according to Azain et al. (2004) the low temperature drying usually preserves the active components in ginger. Eze and Agbo (2011) also recommended the drying temperature of the inner chamber of solar drier not more than $40^{\circ} \mathrm{C}$, as high temperature denatures the protein and alters the organoleptic properties of ginger. The dried powdered ginger reported to contain $9-12 \%$ moisture, $3.6 \%$ fatty oil, $9 \%$ proteins, $60-70 \%$ carbohydrates, $3.8 \%$ crude fibre, $8.0 \%$ ash as compare to fresh ginger which contains $80.9 \%$ moisture, $2.3 \%$ protein, $0.9 \%$ fat, $1.2 \%$ minerals and $2.4 \%$ fibre (Panpatil et al.2013).

Ginger Powder: Ginger powder is made by pulverizing the dry ginger to a mesh size of 50 to 60 (Ravindran and Nirmal 2005). Ginger powder forms an important component in curry powder. It also finds direct application in a variety of food products (Balakrishnan 2005). Pulverization is a physical unit operation whose phenomenon involves size reduction or crushing of the cells and separation of granules 
and is generally a limiting unit operation in ginger processing (Earle 2003). Aderemi et al., (2009) designed and built a medium scale ginger pulverizer. There are two major methods of crushing as traditional and modern methods.

Candies and preserves: Chinese ginger has been the standard for ginger preserved in syrup. Australia has also developed a ginger industry and it exports mostly candied rhizomes with superior and consistent quality (ASTA 2002; Weis 1997).

Salted ginger: Fresh ginger (with relatively low fibre) harvested at $170-180$ days after planting can be used for preparing salted ginger. Tender rhizomes with portion of the pseudo stem is washed thoroughly and soaked in $30 \%$ salt solution containing $1 \%$ citric acid. After 14 days it is ready for use and can be stored under refrigeration.

Ginger oil and oleoresin: The commercial ginger essential oil is characterized by pale yellow colour, warm, spicy and woody flower with slight lemony notes (Koroch et al. 2007). The yield of ginger oil depends upon the cultivar, stage of harvesting and method of extraction etc. On an average the ginger oil content of different cultivar of ginger ranged between 0.85 to 2.00 per cent on dry weight basis (Noor et al. 2004; Sultan et al. 2005; Sasidharan and Menon, 2010). Dry ginger on distillation yields 1.5 to $2.5 \%$ volatile oil. The main constituent in the oil is zingiberene and contributes to the aroma of the oil.

Solvent extraction of ginger oil and oleoresin: Oil extraction is the process of recovering oil from oil-bearing agricultural products through manual, mechanical, or chemical extraction. Extraction of oil from oil-bearing products could be done in two major ways i.e; traditional and slicing/splitting and drying on the organoleptic attributes and nutritional value of ginger (Ibrahim and Onwualu, 2005). The traditional method is usually a manual process and involves preliminary processing and hand pressing. The improved method consists of chemical extraction and mechanical expression. Essential oil is obtained by steam distillation, while oleoresins are obtained by solvent extraction. Oils and oleoresins are preferred to dried spices as flavoring by the food industry, because they are more stable, cleaner, free from contaminations, and can be standardized by blending oils from different sources (Peter and Zachariah 2000). Essential oils are also used in the manufacture of soft drinks, ginger beer, and in food preparation.

\section{NOVEL PRODUCTS FROM GINGER}

Ginger leather/bars: Commercially known as fruit rolls are prepared by dehydrating fruit puree into leathery sheets. It is made by removing the moisture of the fruit puree, using a large flat tray, until the desired cohesive 'leather' is obtained. Fruit leather generally lasts quite a long time and does not require refrigeration (Naz, 2012). Common drying methods used for drying leather are oven-drying (including convection fan forced), sun-drying and electric cabinet drying where cabinet dried leather were found more acceptable (Che Man and Sin, 1997). Dehydrator drying takes approximately four to twelve hours, but the time ultimately depends on the type of raw material, humidity in the room and thickness of the fruit puree. According to Dhiman (2015), a good quality plum ginger leather can be prepared in proportion of 60:40, and 50:50 (plum: ginger) with a recovery of 27.10 to 28.76 per cent with drying time, dehydration ratio, total solids and moisture content of 8.00 to 9.30 hours, 3.48 to $3.69,86.07$ to 86.96 per cent and 13.04 to 13.93 per cent respectively.

Ginger Aroma and juice: The aroma of ginger is pleasant and spicy and its flavour penetrating and biting due to presence of antiseptic or pungent compounds. The aroma and juice can be utilized for the manufacture of a number of food products like ginger bread, confectionery, ginger ale, curry powders, certain curried meats, table sauces, in pickling and in the manufacture of certain soft drinks like cordials, ginger cocktail, carbonated drinks, bitters etc.

Ginger appetized flakes: Kaushal et al. (2016), prepared osmotically dried appetized ginger flakes by using lime juice blanching, followed by dipping in 70 per cent sugar syrup for $4 \mathrm{hrs}$ and rolling of flakes in $2.0 \%$ appetizing mixture. The recovery of osmotically dried ginger flakes ranged between 54.14 to 55.83 per cent with drying hours and drying ratio of 4.20 to 4.25 and 1.79: 1 to 1.84 : 1 respectively.

Ginger paste: Ginger paste was prepared from fresh ginger by Ahmed (2004) by addition of $8 \%$ common salt and citric acid to adjust the $\mathrm{pH}$ from 6.38 to less than 4.6, thermally processing at $80^{\circ} \mathrm{C}$ for 15 minutes and packing in polyethylene terephthalate or glass containers followed by storing at $5 \pm 1^{\circ} \mathrm{C}$. In India, ginger paste is traditionally made with 50\% sliced and macerated ginger, 35\% garlic and 15\% salt (Pruthi 1992).

Crude fibre: In fully matured ginger crude fibre varies from $3-8 \%$. It is estimated by acid and alkali digestion of ginger powder and whatever remains is considered as fibre.

Ginger starch: Pure starch is a white, tasteless and odourless powder containing 20-25\% amylase and $75-80 \%$ amylopectin which is widely used bio-materials in food, textile, cosmetics, plastic, paper and pharmaceutical industries. Thus, ginger is also considered one of the potential source of industrial starch (Kolawole et al. 2013) 
and was found to be white, tasteless with no smell just like maize starch. The percent solubility of ginger starch was calculated as 0.9 percent as against 1.2 percent for maize starch. The starch can be obtained from ginger rhizomes after washing and peeling, the grating is intermittently done to prevent the starch from heating up due to heat from grater. The content is then settled for $2 \mathrm{hrs}$ followed by decantation of yellowish supernatant. Series of re-dispersion and decanting helps in removing impurities and the process results in good quality starch.

Other products: Sweet and salty products can be prepared from fresh ginger like ginger candy, ginger paste, salted ginger, crystallized ginger etc.

\section{CONCLUSION}

Ginger is a spice of commercial and medicinal importance. It is valued because of its aroma and pungency and has been used through ages in almost all systems of medicine against many maladies due to its medicinal properties. Despite of its use as flavoring agent, ginger is also appreciated in ayurvedic, allopathic aromapethy and household medicines. Ginger can be used in the form of fresh paste, ginger tea, dried powder, preserved slices, cookies, candy, teas, tinctures, sodas, jam, beer, capsule and syrup etc. Soft drinks like cordials, ginger cocktail, carbonated drinks, etc are some of the value added products of ginger. Ginger is also used for the extraction of ginger oil, oleoresin, essences, tinctures etc. Ginger has a number of chemical constituents like [6]-Gingerol, [6] -Shagol, Methyl [6] isogingerol, Paradol which are responsible to provide different pharmacological actions like Cardio protective activity, anti-inflammatory activity, anti-microbial activity, antioxidant property, neuro-protective activity and hepatoprotective activities which have been proved. The novel products like ginger bars/rolls, appetized flakes, essential oils \& aroma, juice, paste and starch alongwith ginger candy, salted ginger, crystallized ginger etc. discussed during this review would add value to this amazing crop.

\section{REFERENCES}

[1] Abeysekera WKSM, Illeperuma CK, Amunugoda PNRJ, Wijeratnam S. (2005). Comparison of ginger varieties dried at different temperatures for oil and oleoresin contents. Srilankan J Agric Sci. 42: 34-42

[2] Aderemi BO, Ndirika O, Yerima Y. (2009). Design and fabrication of a medium scale ginger pulverizing machine for rural dwellers. Aus J Basic Appl Sci. 3(2): 389-394
[3] Agrawal YC, Hiran A, Galundia AS. (1987). Ginger peeling machine parameters. Agric Mech Asia Africa Latin Amer. 18(2): 59-62

[4] Aggarwal BB, Shishodia S. (2006). Molecular targets of dietary agents for prevention and therapy of cancer. Biochem Pharmacol. 71: 1397-1421.

[5] Ahmed J. (2004). Rheological behaviour and colour changes of ginger paste during storage. Int J Food Sci Technol. 39: 325-330

[6] Ahmed R, Sharma S. (1997). Biochemical studies on combined effect of garlic (Allium sativum L.) and ginger (Zingiber officinalis) in albino rats. Ind $J$ Experimental Biol, 3(5): 841-843.

[7] Akande EA, Adeyanju JA, Oladipo OA, Oyetunji FF. (2014). Effects of different packaging materials on the shelf stability of ginger juice. Greener Int $J$ Sci, Engineering Technol Res. 4(2): 38-44

[8] Akhtar A, Dash PK, Mannan A. (2013). Physicochemical characterization and product development from ginger (Zingiber officinale). Germplasm available in South Western Region of Bangladesh. IOSR J Agric Vet Sci. 5: 53-62

[9] Alakali JS, Satimehin AA. (2009). Moisture adsorption characteristics of ginger (Zingiber officinale) powders. Agricl Engineering Int. 6: 12861291.

[10] Alam P. (2013). Densitometric HPTLC analysis of 8-gingerol in Zingiber officinale extract and gingercontaining dietary supplements, teas and commercial creams. Asian Pacific J Trop Biomedicine. 3(8):634638.

[11] Ali Y, Jain GC, Kapdi SS, Agrawal YC, Bhatnagar S. (1991). Development of brush type ginger peeling machine. Agric Mech Asia Africa Latin Amer. 22: $71-73$

[12] Ali BH, Blunden G, Tanira MO, Nemmar A. (2008). Some phyto-chemical, pharmacological and toxicological properties of ginger (Zingiber officinale Roscoe): a review of recent research. Food Chem Toxicology. 46(2):409-420.

[13] Altman RD, Macrcussen KC. (2001). Effects of a ginger extract on knee pain in patients with osteoarthritis. J Phytomedicine. 44: 2531-2538

[14] Aruoma OI, Spencer JP, Warren D, Jenner P, Butler J, Halliwell B. (1997). Characterization of food antioxidants, illustrated using commercial garlic and ginger preparations. Food Chem, 6: 49-156.

[15] Arya PS. (2001). Ginger Production Technology. Kalyani Publishers New Delhi. 169p. 
[16] ASTA. (2002). A concise guide to Spices, Herbs, Seeds, and Extractives. Amer Spice Trade Assoc. Magra-Hill Pub. Co. Ltd., New York, p. 51.

[17] Awang DVC. (1992). Ginger. Canad Pharma J. 125:309-311.

[18] Azain MN, Kamal AAF, Azlina MN. (2004). Changes of cell structure in ginger during processing. J Food Engineering. 62:359-364

[19] Balakrishnan KV. (2005). Postharvest and industrial processing of ginger In: Ravindran PN, NirmalBabu $\mathrm{K}$ (eds.) Ginger-The genus Zingiber. CRC Press, Florida. pp. 391-434.

[20] Bartley J, Jacobs A. (2000). Effects of drying on flavour compounds in Australian-grown ginger (Zingiber officinalis). J Sci Food Agric. 80(2): 209215.

[21] Bhuyan S, Prasad S. (1990). Drying characteristics of ginger and development of a small capacity dryer. In: Y. Zeren, Y. Yildiz, M.T. Ozcan, E. Guzel, A. Isik (eds), Proceedings of the $4^{\text {th }}$ International Congress on Agricultural Mechanization \& Energy, Adana. Turkey. pp. 501-509.

[22] Bisset NG, Wichtl M. (1994). Herbal Drugs and Phytopharmaceuticals- A handbook for practice on a scientific basis. Wichtl M, Bisset NG (eds.), Boca Raton, FL: CRC Press.

[23] Bliddal H, Rosetzsky A, Schlichting P, Weidner MS, Andersen LA, Ibfelt HH, Christensen K, Jensen ON, Barslev J. (2000). A randomized, placebo-controlled, cross-over study of ginger extracts and ibuprofen in osteoarthritis. Osteoarthritis Cartilage. 8(1): 9-12.

[24] Bolanle AO. (2011). Effect of ginger powder (Zingiber officinale) on plasma lipid profile and liver enzyme activities of hypercholesterolemic rats. J Life Sci. 5:712-716.

[25] Bryer E. (2005). A literature review of the effectiveness of ginger in alleviating mild-tomoderate nausea and vomiting of pregnancy. $J$ Midwifery Women's Health. 50(1): e1-e3.

[26] Camacho EH, Brescia A. (2009). The Australian ginger industry: Overview of Market Trends and Opportunities. Ginger: The Genus Zingiber. CRC Press, Florida, U.S.A. http://www.daff.qld.gov.au/data/assets.

[27] Cao ZF, Chen ZG, Guo P, Zhang SM, Lian LX, Luo L, Hu WM. (1993). Scavenging effects of ginger on superoxide anion and hydroxyl radical. Chung-Kuo Chung Yao Tsa Chih. 18:750-764.

[28] Chatthong B, Sarazin Y, Onjun T. (2011) Analytical and Numerical Modelling of Transport Barrier
Formation Using Bifurcation Concept. 38th EPS Conference on Plasma Physics (Strasbourg, France), Paper P4.097.

[29] Che Man YB, Sin KK. (1997). Processing and consumer acceptance of fruit leather from the unfertilised floral parts of jackfruit. J Sci Food Agric. 75(1):102-108.

[30] Chen IN, Chang CC, Ng CC, Wang CY, Shyu YT, Chang TL. (2008). Antioxidant and antimicrobial activity of zingiberaceous plants in Taiwan. Plants Foods Hum Nutr. 63:15-20.

[31] Dhiman A. (2015). Development and evaluation of novel products from ginger (Zingiber officinale). M.Sc. Thesis. p114.

[32] Dhingra S, Kumar A. (2005). Post harvest technology of ginger. Ind CorxArecanut Spice J. 14(1): $13-15$

[33] Dohroo NP, Sharma IL. (1986). Evaluation of fungicides for the control of rhizome rot of ginger in storage. Indian Phytopath. 36:691-693

[34] Earle RL. (2003). Size reduction. In: Unit Operations in Food Processing. www.nzifst/org.nz/unit operations/size reduction.

[35] Ebewele RO, Jimoh AA. (1988). Feasibility study of kaduna state ginger processing industry. Ahmadu Bello University Chemical Engineering consultant, pp. $63-80$

[36] Ehsanullah Raheem MI, Ahmad T, Hayat S. (2013). Effect of potassium metabisulphite and salt solution on ginger puree and its storage. J Agric Res. 51(3): 297-305

[37] El-Baroty GSHH, Farag RS, Saleh MA. (2010). Characterization of antioxidant \& antimicrobial compounds of cinnamon and ginger essential oils. African J Biochem Res. 4(6): 167-174

[38] Elaissi A, Salah K, Mabrouk S, Larbi K, Chemli R. (2011). Antibacterial activity and chemical composition of 20 Eucalyptus species essential oils. Food Chem. 129: 1427-1434

[39] EL-Ghorab AH, Nauman M, Anjum FM, Hussain S, Nadeem MA. (2010). Comparative study on chemical composition and antioxidant activity of ginger (Zingiber officinale) and cumin (Cuminum cyminum). J Agric Food Chem. 58: 8231-8237

[40] Endrais G, Asfaw K. (2011). Production, processing and marketing of ginger in Southern Ethiopia. $J$ Horti Forestry. 3(7):207-213.

[41] Eze JI, Agbo KE. (2011). Comparative studies of sun and solar drying of peeled and unpeeled ginger. Amer J Scientific Indl Res. 2(2): 136-143 
[42] FAO (2014). Food and Agriculture Organization, Rome. www.fao.org.in. Accession date: $\left(15^{\text {th }} \mathrm{Jan}\right.$, 2014)

[43] Fessenden JM, Wittenborn W, Clarke L. (2001). Gingko biloba: A case report of herbal medicine and bleeding postoperatively from a laparoscopic cholecystec-tomy. Am Surg. 67(1): 33-35.

[44] Ficker CE, Arnason JT, Vindas PS, Alvarez LP, Akpagana K, Smith Ml. (2003). Inhibition of human pathogenic fungi by ethno-botanically selected plant extracts. Mycoses. 46 (1-2): 29-

[45] Ghayur MN, Gilani AH, Afridi MB, Houghton PJ. (2005). Cardiovascular effects of ginger aqueous extract and its phenolic constituents are mediated through multiple pathways. Vasc Pharm. 43(4): 234241.

[46] Ghosh AK, Banerjee S, Mullick HI, Banerjee J. (2011). Zingiber Officinale: a natural gold. Int

[47] J Pharma Bio Sci. 2(1): 283-294.

[48] Giriraju A, Yunus GY. (2013). Assessment of antimicrobial potential of $10 \%$ ginger extract against Streptococcus mutans, Candida albicans and Enterococcus faecalis: an in-vitro study. Indian $J$ Dent Res. 24: 397-400.

[49] Gopalan C, Ramasastri BV, Balasubramanium SC. (2004) Nutritive value of Indian foods. National Institute of Nutrition, Indian Council of Medical Research, Hyderabad. p 48-50

[50] Govindarajan VS. (1982). Ginger: Chemistry, technology and quality evaluation. Crit Rev Food Sci Nutr. 7: 1-96

[51] Grant KL, Lutz RB. (2000). Alternative therapies: ginger. Amer J Health-System Pharm. 57: 945-947

[52] Grzanna R, Lindmark L, Frondoza C. (2005). Ginger-a herbal medicinal product with broad antiinflammatory actions. J Medicine Food. 8(2): 125132.

[53] Guwo AN. (2008). Development of a ginger splitting machine. M.Sc. Thesis. Department of Agric. Engineering, ABU, Nigeria.

[54] Gupta R, Singh B, Shivhare S. (2012). Optimization of osmo-convective dehydration process for the development of honey-ginger candy using response surface methodology. Drying Technol. 30: 750-759

[55] Hasan HA, Rasheed Raauf AM, Abd Razik BM, Rasool Hassan BA. (2012). Chemical composition and antimicrobial activity of the crude extracts isolated from Zingiber officinale by different solvents. Pharmaceut Anal Acta. 3: 184
[56] Hasnat M, Rajib B, Hossain MA, Anam MM, Kabir H. (2014). Effect of chemicals, bio-agent, plant extract and soil amendments in controlling rhizome rot of ginger. Int J Nat Soc Sci. 1: 1-11.

[57] Hossain MA, Shah MD, Sang SV, Sakari M. (2011). Chemical composition and antibacterial properties of the essential oils and crude extracts of Merremia borneesis. J King Saud Univ-Sci. 24: 243-249

[58] Ibrahim I, Onwualu AP. (2005). Technologies for extraction from oil-bearing agricultural products: A review. J Agricl Engineering Technol. 13: 58-70.

[59] Islam K, Rowsni AA, Khan M, Kabir MS. (2014). Antimicrobial activity of ginger (Zingiber officinale) extracts against food-borne pathogenic bacteria. Int $J$ Sci, Environment Technol. 3(3): 867-871.

[60] ITC. (2002). International Trade Center UNCTAD/WTO. Global Spice Market: Imports1996-2000. Geneva: ITC, 2002. xxii, 80 p.

[61] Jadhav MS, Nimbalkar CA, Kanawade VL. (2012). Drying behaviour of ginger (cv Mahim). Bioinfolet. 9: $778-783$

[62] Jayashree E, Visvanathan. (2011). Physical and biochemical parameters of fresh and dry ginger (Zingiber officinale Roscoe). J Spices Arom Crops. 20(1): 14-21

[63] Jayashree E, Kandiannan K, Prasath D, Rashid P, Sasikumar B, Kumar SCM, Srinivasan V, Susheela BR, Thankamani CK. (2014). Ginger (Extension Pamphlet). ICAR- Indian Institute of spice Research, Kozhikode, Kerala. pp. 1-10

[64] Jayashree E, Visvanathan R. (2013). Development of hand operated diamond cut mesh drum abrasive ginger peeler. J Spices Arom Crops. 22(2): 174-180.

[65] Joshi AK, Rathore JS, Ali Y. (1991). Economoic analysis of ginger processing technology for rural areas. Bev Food World. 18(2): 27-29

[66] Kaushal M, Kumar N, Vaidya D. (2014). Processing quality of ginger (Zingiber officinale) land races in Himachal Pradesh. Int J Farm Sci. 4(3): 110-116

[67] Kaushal M, Dhiman A, Gupta A, Vaidya D. (2016). Effect of blanching on quality characteristics of osmotically dried and appetized ginger flakes. Ind $J$ Natural Prod Res (In press) MS No-2349-1296.

[68] Kirtiraj K, Gaikwad, Singh S, Shakya BR. (2013). Studies on the development and shelf life of low calorie herbal aonla-ginger RTS beverage by using artificial sweeteners. J Food Proc Technol. 4(1):2

[69] Kizhakkayil J, Sasikumar B. 2009.Variabilty for quality traits in a global germplasm collection of 
ginger (Zingiber officinale R.). Curr Trends Biotechnol Phar. 3(3): 254 -259

[70] Koroch A, Ranarivelo L, Behra O, Juliani HR, Simon JE. (2007). Quality attributes of ginger and cinnamon essential oils from Madagascar. Botanicals Med. 5: 25-38

[71] Kolawole SA, Igwemmar NC, Bello HA. (2013). Comparison of the physicochemical properties of starch from ginger (Zingiber officinale) and Maize (Zea mays). Int J Sci Res. 71-76.

[72] Krishnakantha TP, Lokesh BR. (1993). Scavenging of superoxide anions by spice principles. Ind J Biochem Biophys. 30:133-134.

[73] Kubra IR, Rao LJM. (2012). An impression on current developments in the technology, chemistry, and biological activities of ginger (Zingiber officinale Roscoe). Crit Rev Food Sci Nutr. 52(8):651-688.

[74] Langner E, Greifenberg S, Gruenwald J. (1998). Ginger: history and use. Adv Therapy. 15(1):25-44.

[75] Latona DF, Oyeleke GO, Olayiwada OA. (2012). Chemical analysis of ginger root. IOSR $J$ Applied Chem. 1(1): 47-49.

[76] Ling H, Yang H, Tan SH, Chui WK, Chew EH. (2010). 6-shogaol, an active constituent of ginger, inhibits breast cancer cell invasion by reducing matrix metalloproteinase-9 expression via blockade of nuclear factor- $\kappa \mathrm{b}$ activation. British J Pharma, 161(8), 1763-1777.

[77] Liu Y, Whelan RJ, Pattnaik BR, Ludwig K, Subudhi E, Rowland H, Claussen N, Zucker N, Uppal S, Kushner DM, Felder M, Patankar MS, Kapur A. (2012). Terpenoids from Zingiber officinale (Ginger) induce apoptosis in endometrial cancer cells through the activation of p53. PLoS One. 7(12): e53178 (110).

[78] Mallorea R, Leon De SY, Lim-sylianco CY. (1992). Free glutamic acid in some Philippine fruits and vegetables. Asean Food J. 7(2): 100-110

[79] Maizura M, Aminath A, Wan AWM. (2011). Total phenolic content and antioxidant activity of kesum (Polygonum minus), ginger (Zingiber officinale) and turmeric (Curcuma longa) extract. Int Food Res J. 18: $529-534$

[80] Meadows AB. (1998). Ginger processing for food and industry. In: Proceedings of first National ginger workshop. Umudike, Nigeria, pp. 34-42.

[81] Maxwell I. (2008). Let's make ginger beer. Dave's Garden.

[82] Minaiyan M, Ghannadi A, Karimzadeh A. (2006). Anti-ulcerogenic effect of ginger (rhizome of
Zingiber officinale roscoe) on cystemine induced duodenal ulcer in rats. DARU J Pharma Sci. 14(2): 97-101.

[83] Miyoshi N, Nakamura Y, Ueda Y, Abe M, Ozawa Y, Uchida K and Osawa T. (2003). Dietary ginger constituents, galanals $\mathrm{A}$ and $\mathrm{B}$ are potent apoptosis inducers in Human T lymphoma Jurkat cells. Cancer Lett. 199: 113-119.

[84] Michiein EM, Salvador AA, Reihi CA, Smania AJr, Smania EF. (2009). Chemical composition and antibacterial activity of Cordia veribenacea extracts obtained by different methods. Bioresource Tech. 100: 6615-6623.

[85] Nath A, Bidyut C, Deka AK, Paul JD, Misra LK. (2013). Effect of slice thickness and blanching time on different quality attributes of instant ginger candy. J Food Sci Technol. 50(1): 197-202

[86] Naz R. (2012). Physical properties, sensory attributes and consumer preference of fruit leather. Pak J Food Sci. 22(4): 188-190.

[87] Nicoll R, Henein MY. (2009). Ginger (Zingiber officinale roscoe): A hot remedy for cardiovascular disease? Int J Cardiol. 131(3):408-409.

[88] Noor AM, Mustafa K, Azlina MN. (2004). Changes of cell structure in ginger during processing. Food Engineering. 62(4): 359-364

[89] Nwaoha M, Elizabeth I, Okafor, Gabriel I, Apochi, Veronica O. (2013). Production of oleoresin from ginger (Zingiber officinale) peels and evaluation of its antimicrobial and antioxidative properties. Afr J Microbiol Res. 7(42): 4981-4989

[90] Nwinuka N, Ibeh G, Ekeke G. (2005). Proximate composition and levels of some toxicants in four commonly consumed spices. J Appl Sci Environ Mgt. 9(1): 150-155.

[91] Nurtjahja-Tjendraputra E, Ammit AJ, Roufogalis BD, Tran VH, Duke CC. (2003). Effective antiplatelet and cox-1 enzyme inhibitors from pungent constituents of ginger. Thromb Res. 111(4): 259-265.

[92] Offei-Okyne R, Patterson J, Walker LT, Verghese M. (2015). Processing effects on phyto-chemical content and antioxidative potential of ginger. Food Nutr Sci. 6: 445-451.

[93] Okolo SC, Olajide Olutayo O, Idowu DI, Adebiyi AB, Ikokoh PP, Orishadipe AT. (2012). Comparative proximate studies on some Nigerian food supplements. Ann Biological Res. 3(2):773-779

[94] Onu LT, Okafor G. (2002). Effect of physical and chemical factor variations on the efficiency of 
mechanical slicing of Nigerian ginger (Zingiber

officinale Rosc.). J Food Engineering. 63: 299-302

[95] Onwuka GI, Nwokoha GU, Asumugha GN (2002). Evaluation of processing methods for the production of ginger drinks. Proceedings of $26^{\text {th }}$ Annual NIFST Conference, Owerri.

[96] Overy DP, Frisvad JC. (2005). Mycotoxin Production and Postharvest Storage Rot of Ginger (Zingiber officinale) by Penicillum brevibacterium. J Food Prot. 68 (3): 607-609

[97] Panhwar F. (2005). Ginger (Zingiber officinale) cultivation in Sindh Pakistan. Digitalverlag Gmbh Publishing, Germany, p1-5.

[98] Panpatil VV, Tattari S, Kota N, Nimgulkar C, Polasa $\mathrm{K}$. (2013). In vitro evaluation on antioxidant and antimicrobial activity of spice extracts of ginger, turmeric and garlic. J Pharmacognosy Phytochem. 2 (3): $143-148$

[99] Paull RE, Chen NJ, Goo TTC. (1988). Compositional changes in ginger rhizomes during storage. J Amer Soc Hortic Sci. 113:584-588.

[100] Paull RE, Chen CC. (2015). Ginger postharvest quality-maintenance guidelines. Vegetable Root Crops $J$. UH-CTAHR VC-2:1-3.

[101] Peter KV, Zachariah TJ. (2000). Spice oils and oleoresins: Challenges and opportunities. $J$ Medicinal Arom Plant Sci. 22 (1):247-252.

[102] Phoungchandang S, Sertwasana A. (2010). Spraydrying of ginger-juice and physico-chemical properties of ginger powders. Sci Asia. 36: 40-45

[103] Prabhakaran KP. (2013).The agronomy and economy of turmeric and ginger [electronic resource] : the invaluable medicinal spice crops . Burlington : Elsevier Science, p 537.

[104] Pruthi JS. (1992). Postharvest technology of spices: pre-treatments, curing, cleaning, grading and packing. J Spices Arom Crops. 1 (1):1-29.

[105] Pruthi, J.S. 1998. Spices and condiments. National Book Trust ( $5^{\text {th }}$ Ed.) New Delhi, India. p 1-325.

[106] Puengphian C, Sirichote A. (2008). [6]-gingerol content and bioactive properties of ginger (Zingiber officinale Roscoe) extracts from supercritical $\mathrm{CO}_{2}$ extraction. Asian J Food Agro Industry. 1(10): 29-36

[107] Purnomo H, Jaya F, Widjanarko SB. (2010). The effects of type and time of thermal processing on ginger (Zingiber officinale Roscoe) rhizome antioxidant compounds and its quality. Int Food Res J. 17: 335- 347
[108] Purseglove JW, Brown EG, Green CL, Robbins SRJ. (1981). Ginger. In: Spices. Vol. II. Longman, New York. pp. 447-531

[109] Qidwai W, Alim SR, Dhanani RH, Jehangir S, Nasrullah A, Raza A. (2003). Use of folk remedies among patients in Karachi Pakistan. J Ayub Medical College Abbottabad. 15(2):31-33.

[110] Rahman MJ, Talukder MAI, Rani L, Saha KC, Nahid MSI. (2013). The effect of processing techniques on the shelf life, nutritional and sensory quality of ginger (Zingiber officinale) powder and paste. J Innov Develop Strat. 7(3): 60-66

[111] Ravindran PN, Nirmal-Babu K. (2005). Introduction. In: Ginger: the genus Zingiber. (Eds.): P.N. Ravinderan and B.K. Nirmal. CRC Press, New York, pp 1-14.

[112] Reddy AA, Lokesh BR. (1992). Studies on spice principles as antioxidants in the inhibition of lipid peroxidation of rat liver microsomes. Mol Cell Biochem. 111:117-124.

[113] Safaa YQ, Ahmed N, Abo-Khatwa, Mona ABL. (2010). Screening of antioxidant activity and phenolic content of selected food items cited in the Holy Quran. J Biol Sci. 2(1):40-51.

[114] Sagar SD. (2006). Investigations on the etiology, epidemiology and integrated management of rhizome rot complex of ginger and turmeric. Ph.D. Thesis, Department of Plant Pathology, University of Agricultural Sciences, Dharwad- 580005.

[115] San Chang J, Wang KC, Yeh CF, Shieh DE, Chiang LC. (2013). Fresh ginger (Zingiber officinale) has anti-viral activity against human respiratory syncytial virus in human respiratory tract cell lines. $J$ Ethnopharmacology. 145(1):146-151.

[116] Sasidharan I, Menon AN. (2010). Comparative chemical composition and antimicrobial activity fresh \& dry ginger oils (Zingiber officinale Roscoe). Int J Curr Pharma Res. 2(4):40-43.

[117] Sebioma A, Awofodu AD, Awosanya AO, Awotona FE, Ajayi AJ. (2011). Comparative studies of antibacterial effect of some antibiotics and ginger (Zingiber officinale) on two pathogenic bacteria. $J$ Microbiol Antimicrobials. 3:18-22.

[118] Shahid M, Hussain F. (2012). Chemical composition and mineral content of Zingiber officinale and Alpinia allughas (Zingiberaceae) rhizomes. Int $J$ Chem Biochem Sci. 2: 101-104

[119] Sharma SK, Dohroo NP. (1991). Postharvest management of rhizome rot (Fusarium oxysporum f.sp. zingiberi trujillo) of ginger through chemical 
and antagonist. Ind Cocoa, Areca Spices J. 14: 150152.

[120] Shelly TE, Mcinnis DO, Pahio E, Edu J. (2004). Aromatherapy in the Mediterranean fruit fly (diptera: Tephritidae): Sterile males exposed to ginger root oil in prerelease storage boxes display increased mating competitiveness in field-cage trials. $J$ Economic Entomology. 97(3): 846-853.

[121] Shanmugam KR, Mallikarjuna K, Kesireddy N, Reddy KS. (2011). Neuroprotective effect of ginger on anti-oxidant enzymes in streptozotocin-induced diabetic rats. Food Chem Toxicology. 49(4): 893897.

[122] Shirin APR, Prakash. (2010). Chemical composition and antioxidant properties of ginger root (Zingiber officinale). J Medicinal Plants Res. 4(24): 2674-267

[123] Shirshir Md RI, Hossain M, Hossain Md. M. (2012). Processing of ginger powder. Bangladesh Res Pub J. 7(3): 277-282.

[124] Shukla Y, Singh M. (2007). Cancer preventive properties of ginger: a brief review. Food Chemical Toxicol. 45(5): 683-690.

[125] Simonyan KJ, Jegede KM, Lyocks SW. (2003). Development of a motorized Ginger Slicer. Agric Mech Asia, Africa Latin Amer. 34 (1): 37-41.

[126] Singh K, Bawa AS, Ahmed J. (2001). Dehydration of ginger slices. J Scientific Industrial Res. 60:510512

[127] Singh G, Kapoor IP, Singh SP, Heluani CS, Lampasona MP, Catalan CA. (2008). Chemistry, antioxidant and antimicrobial investigations on essential oil and oleoresins of Zingiber officinalis. Food Chem Toxicol. 4(6): 3295-302.

[128] Siddiqui AA, Bhuiyan MHR, Easdani M. (2012). Ginger (Zingiber officinale) preserve and candy development. Bangladesh Res Publ J. 7(3): 283-290

[129] Sloand ED, Vessey JA. (2001). Self-medication with common household medicines by young adolescents. Compr Pediatr Nurs. 24(1): 57-67.

[130] Srivastava KC, Mustafa T. (1989). Ginger (Zingiber officinale) and rheumatic disorders. Med Hypotheses. 29(1): 25-28.

[131] Sultan MHN, Bhatti, Iqbal Z. (2005). Chemical analysis of essential oil of ginger (Zingiber officinale). Pak J Biol Sci. 8(11): 1576-1578

[132] Tan BKH, Vanitha J. (2004). Immunomodulatory and antibacterial effects of some traditional Chinese medicinal herbs: a review. Curr Med Chem. 11(11):1423-1430.

[133] Tanveer S, Shahzad A, Ahmed W. (2014).Compositional and mineral profiling of Zingiber officinale. Pak J Food Sci. 24(1): 21-26

[134] Tepe B, Sokmen M, Akpulat HA, Sokmen A. (2006). Screening of the antioxidant potentials of six Salvia species from Turkey. Food Chem. 9(5): 200204.

[135] Thakore BBL, Mathur S, Singh RB. (1988). Effect of rhizome treatment with fungicides for economic control of rot. J Phytol Res. 1: 83-84.

[136] Tjendraputra E, Tran VH, Biu-Brennan D, Roufogalis BD, Duke CC. (2001). Effect of ginger constituents and synthetic analogues on cyclooxygenase-2 enzyme in intact cells. Bioorg Chem. 29: 156-163.

[137] Vats V, Grover JK, Rathi SS. (2002). Evaluation of anti-hyperglycemic and hypoglycemic effect of Trigonella foenum-graecum linn, Ocimum sanctum linn and Pterocarpus marsupium linn in normal and alloxanized diabetic rats. J Ethnopharmacol. 79(1): 95-100.

[138] Virendra V, Tattari S, Kota N, Nimgulkar C, Polasa K. (2013). In vitro evaluation on antioxidant and antimicrobial activity of spice extracts of ginger, turmeric and garlic. J Pharmacognosy Phytochem. 2(3): 143-148

[139] Wang X, Zheng ZJ, Guo XF, Yuan JP, Zheng CC. (2011). Preparative separation of gingerols from Zingiber officinale by high-speed counter-current chromatography using stepwise elution. Food Chem. 125: $1476-1480$

[140] Weiss EA. (1997). Essential Oil Crops. CAB International publishing, Oxon, UK.

[141] Yiljep Y, Fumen G, Ajisegiri E. (2005). The Effects of peeling, splitting and drying on ginger quality. Agricultural Engineering International: CIGR E J. Manuscript FP 05 009, 7.

[142] Zick SM, Djuric Z, Ruffin MT, Litzinger AJ, Normolle DP, Alrawi S, Feng MR, Brenner DE. (2008). Pharmacokinetics of 6-gingerol, 8-gingerol, 10-gingerol, and 6-shogaol and conjugate metabolites in healthy human subjects. Cancer Epidemiol Biomarkers Prev. 17:1930-1936. 
Table.1: Mode of action of active constituents present in ginger.

\begin{tabular}{|c|c|c|c|}
\hline Active constituents & Biological action & Mode of action & References \\
\hline $\begin{array}{lr}\text { Gingerols, } & \text { shogaols, } \\
\text { Sesquit-erpenes } & \text { and } \\
\text { monoterpenes) } & \end{array}$ & $\begin{array}{l}\text { For the treatment of nausea } \\
\text { and vomiting }\end{array}$ & $\begin{array}{l}\text { By anti-cholinergic and } \\
\text { anti-serotonin action }\end{array}$ & Bryer, 2005 \\
\hline Ethanolic extract of ginger & Hypolipidimic agent & $\begin{array}{l}\text { By reducing triglycerides } \\
\text { and LDL cholesterol and } \\
\text { to increase HDL }\end{array}$ & Bolanle, 2011 \\
\hline $\begin{array}{l}\text { Anticancer activities (e.g. } \\
\text { breast cancer) }\end{array}$ & inhibition of cell invasion & $\begin{array}{l}\text { reduction of matrix } \\
\text { metalloproteinase-9 } \\
\text { expression }\end{array}$ & Ling et al., 2010 \\
\hline $\begin{array}{l}\text { Zingiberone and ethanolic } \\
\text { extract of ginger }\end{array}$ & Anti-hyperglycemic effect & $\begin{array}{l}\text { Lowering of blood glucose } \\
\text { level by inhibition of } \\
\text { oxidative stress and anti- } \\
\text { inflammatory process, } \\
\text { increase insulin sensitivity. }\end{array}$ & $\begin{array}{l}\text { Vats et al., } 2002 ; \\
\text { Shanmugam et } \text { al., } 2011\end{array}$ \\
\hline $\begin{array}{l}\text { Phenolic and favonoids } \\
\text { compounds }\end{array}$ & Neuroprotector effect & $\begin{array}{l}\text { by accelerating brain anti- } \\
\text { oxidant defense } \\
\text { mechanisms }\end{array}$ & Shanmugam et al., 2011 \\
\hline $\begin{array}{l}\text { Ginger extract (highly } \\
\text { purified and standardized) }\end{array}$ & $\begin{array}{l}\text { Treatment of osteoarthritis } \\
\text { of the knee joints }\end{array}$ & $\begin{array}{l}\text { By reduction of } \\
\text { inflammatory mediators. }\end{array}$ & $\begin{array}{l}\text { Bliddal et al., 2000; } \\
\text { Altman and Marcussen, } \\
2001\end{array}$ \\
\hline $\begin{array}{l}\text { [6]-gingerol and [6]- } \\
\text { shogaol }\end{array}$ & $\begin{array}{l}\text { anti-ulcerative effects } \\
\text { Hypotensive effects }\end{array}$ & $\begin{array}{l}\text { By Suppressing the gastric } \\
\text { contrac-tion, increasing } \\
\text { mucin secretion } \\
\text { lowering blood pressure by } \\
\text { inhibition of voltage- } \\
\text { dependent } \\
\text { channels as well as by } \\
\text { stimulating muscarinic } \\
\text { receptors }\end{array}$ & $\begin{array}{l}\text { Minaiyan et al., } 2006 \\
\text { Ghayur et al., } 2005 \text {; Nicoll } \\
\text { and Henein, } 2009\end{array}$ \\
\hline $\begin{array}{l}\text { Sesquiterpenes } \\
\text { Sesquiphellandrene }\end{array}$ & Anti-viral effect & & San Chang et al., 2013 \\
\hline Gingerol and shogaol & Antiplatelet activity & \begin{tabular}{lrr} 
lower & \multicolumn{2}{r}{ platelet } \\
thromboxane & X2 & and \\
prostaglandin & & E2 \\
production & &
\end{tabular} & $\begin{array}{l}\text { Nurtjahja-Tjendraputra et } \\
\text { al., } 2003\end{array}$ \\
\hline
\end{tabular}

Table.2: Quality characteristics of fresh ginger rhizome

\begin{tabular}{|r|l|l|l|}
\hline S.No. & Parameters & Range & References \\
\hline 1. & Length $(\mathrm{cm})$ & $4.80-14.99$ & $\begin{array}{l}\text { Kaushal et al. 2014; Kirtiraj et al. 2013; Akhtar et al. 2013; } \\
\text { Jayashree \& Vishvanathan 2011 }\end{array}$ \\
\hline 2. & Width $(\mathrm{cm})$ & $1.82-8.17$ & $\begin{array}{l}\text { Kaushal et al. 2014; Akhtar et al. 2013; Kirtiraj et al. 2013; } \\
\text { Jayashree \& Vishvanathan 2011 }\end{array}$ \\
\hline 3. & Thickness $(\mathrm{cm})$ & $3.25-4.49$ & Kaushal et al. 2014; Jayashree \& Vishvanathan 2011 \\
\hline 4. & Weight $(\mathrm{g})$ & $8.0-161.6$ & $\begin{array}{l}\text { Kirtiraj et al. 2013; Akhtar et al. 2013; Jayashree \& Visvanathan } \\
\text { 2011; Onu and Okafor 2002 }\end{array}$ \\
\hline 5. & Volume $\left(\mathrm{cm}^{3}\right)$ & $64.0-85.0$ & Jayashree \& Visvanathan 2011; Onu and Okafor 2002 \\
\hline
\end{tabular}




\begin{tabular}{|c|c|c|c|}
\hline 6. & Density & $0.88-1.02$ & Ghosh et al. 2011; Phoungchandang and Sertwasana 2010 \\
\hline 7. & Moisture (\%) & $75.20-94.17$ & $\begin{array}{l}\text { Tanveer et al. 2014; Kaushal et al. 2014; Ghosh et al. 2011; Eze and } \\
\text { Agbo 2011; Phoungchandang and Sertwasena 2010; Puengphian and } \\
\text { Sirichote 2008; Singh et al. 2001; }\end{array}$ \\
\hline 8. & $\begin{array}{l}\text { Total soluble solids } \\
\left({ }^{\circ} \mathrm{B}\right)\end{array}$ & $3.33-6.67$ & Kaushal et al. 2014; Eze and Agbo 2011 \\
\hline 9. & Carbohydrates $(\%)$ & 12.3 & Ehsanullah et al. 2013 \\
\hline 10. & $\begin{array}{l}\text { Ascorbic } \quad \text { acid } \\
(\mathrm{mg} / 100 \mathrm{~g})\end{array}$ & $1.04-9.33$ & $\begin{array}{l}\text { Latona et al. 2012; Shahid and Hussain 2012; Shirin and Prakash } \\
2010\end{array}$ \\
\hline 11. & $\mathrm{pH}$ & $5.23-6.72$ & $\begin{array}{l}\text { Kaushal et al. 2014; Akhtar et al. 2013; Rahman et al. 2013; } \\
\text { Shirshir } \text { et al. 2012. }\end{array}$ \\
\hline 12. & $\begin{array}{l}\text { Phenols } \quad(\mathrm{mg} \\
\text { GAE/100g) }\end{array}$ & $24.63-514.02$ & $\begin{array}{l}\text { Oknye et al. 2015; Saffa et al. 2010; EL-Ghorab et al. 2010; } \\
\text { Puengphian and Sirichote } 2008\end{array}$ \\
\hline 13. & $\begin{array}{l}\text { Antioxidant activity } \\
(\%)\end{array}$ & $51.01-79.19$ & $\begin{array}{l}\text { Kaushal et al. 2014; Nwaoha et al. 2013; Maizura et al. 2011; } \\
\text { Purnomo et al. 2010; Grant and Lutz } 2000\end{array}$ \\
\hline 14. & Starch $(\%)$ & $40.4-59.0$ & Akande et al. 2014; Jadhav et al. 2012 \\
\hline 15. & Proteins $(\%)$ & $1.2-15.0$ & $\begin{array}{l}\text { Ehsanullah et al. 2013; Shahid and Hussain 2012; Okolo et al. 2012; } \\
\text { Ghosh et al. 2011; EL-Ghorab et al. 2010; Dhingra and Kumar } \\
\text { 2005; Nwinuka et al. 2005; Panhwar 2005; Mallorea et al. } 1992\end{array}$ \\
\hline 16. & Fat $(\%)$ & $0.9-1.0$ & Ehsanullah et al. 2013; Ghosh et al. 2011 \\
\hline 17. & Fibre $(\%)$ & $0.50-10.8$ & $\begin{array}{l}\text { Kaushal et al. 2014; Ehsanullah et al. 2013; Virendra et al. 2013; } \\
\text { Jadhav et al. 2012; Kizhakkayil and Sasikumar 2009; Singh et al. } \\
2001\end{array}$ \\
\hline 18. & $\operatorname{Ash}(\%)$ & $0.69-2.3$ & $\begin{array}{l}\text { Kaushal et al. 2014; Rahman et al. 2013; Shahid and Hussain 2012; } \\
\text { Ghosh et al. 2011; El-Ghorab et al. 2010; Singh et al. 2001; Gopalan } \\
\text { et al. } 2004\end{array}$ \\
\hline 19. & Oleoresin $(\%)$ & $3.30-13.65$ & Jayashree et al. 2014; Abeysekera et al. 2005 \\
\hline 20. & Volatile oil (\%) & $0.85-2.70$ & $\begin{array}{l}\text { Sasidharan and Menon 2010; EI-Baroty et al. 2010; Sultan et al. } \\
\text { 2005; Noor et al. 2004; Singh et al. } 2001\end{array}$ \\
\hline
\end{tabular}

Table.3: Postharvest diseases of ginger

\begin{tabular}{|c|c|c|c|}
\hline Disease & $\begin{array}{l}\text { Causative } \\
\text { agent }\end{array}$ & Symptoms & Control \\
\hline Soft Rot & $\begin{array}{l}\text { Pythium } \\
\text { common soil- } \\
\text { borne fungus }\end{array}$ & $\begin{array}{l}\text { Small brownish spots on the skin, } \\
\text { which may rapidly enlarge into } \\
\text { sizeable lesions. As the decay } \\
\text { progresses, the tissue breaks } \\
\text { down into a soft and watery mass. }\end{array}$ & $\begin{array}{l}\text { Chemicals such as mancozeb, ziram, } \\
\text { guazatine, propineb and copper oxychloride } \\
\text { (30 minutes dip) treatments for rhizomes. } \\
\text { Ridomil MZ @ } 1.25 \mathrm{~g} / \mathrm{L} \text { increased survival } \\
\text { of rhizomes by about 30\%.(Dohroo and } \\
\text { Sharma 1986; Thakore et al. 1988) }\end{array}$ \\
\hline $\begin{array}{ll}\text { Dry } & \text { Rot/ } \\
\text { Yellows } & \end{array}$ & $\begin{array}{l}\text { Fusarium } \\
\text { Soil-borne } \\
\text { fungus }\end{array}$ & $\begin{array}{l}\text { Off-coloured dry sunken lesions } \\
\text { typically border by a brown } \\
\text { margin on the rhizome surface. } \\
\text { Internal symptoms include a pale } \\
\text { brown discolouration of the } \\
\text { vascular tissue. }\end{array}$ & $\begin{array}{l}\text { Systemic and contact fungicides like } \\
\text { Bavistin 50WP, Ridomil Gold MZ-72, } \\
\text { Captan, Dithane M- } 445 \text {, copper oxychloride } \\
\text { and Bordeaux mixture etc. were reported } \\
\text { effective against the disease (Sagar 2006; } \\
\text { Hasnat et al. 2014) }\end{array}$ \\
\hline Blue Mould & $\begin{array}{l}\text { Penicillium } \\
\text { fungus }\end{array}$ & $\begin{array}{l}\text { Develops on cut ends and injured } \\
\text { areas and result in internal tissue } \\
\text { decay. }\end{array}$ & \\
\hline Watery Rot & Rhizopus & Soft, watery rot progresses & The post-harvest fungicide 2,6 dichloro- 4 \\
\hline
\end{tabular}




\begin{tabular}{|c|c|c|c|}
\hline & fungus & $\begin{array}{l}\text { rapidly and rot an entire rhizome } \\
\text { in a week. Infected tissue is } \\
\text { mottled brown and soft and in a } \\
\text { humid atmosphere the infected } \\
\text { area is soon covered with white } \\
\text { mould which eventually turns } \\
\text { black. }\end{array}$ & $\begin{array}{l}\text { nitroaniline (Botran) is applied just prior to } \\
\text { packing may reduce watery rot during } \\
\text { transport to export market destinations. }\end{array}$ \\
\hline $\begin{array}{l}\text { Bacterial Soft } \\
\text { Rot }\end{array}$ & $\begin{array}{l}\text { Erwinia } \\
\text { carotovora }\end{array}$ & $\begin{array}{l}\text { Principal postharvest bacterial } \\
\text { disease of ginger. A soft wet rot } \\
\text { of the tissue, which has a strong } \\
\text { foul odour, the severity of disease } \\
\text { is rapid under warm humid } \\
\text { conditions. }\end{array}$ & $\begin{array}{l}\text { Control includes harvesting at full maturity, } \\
\text { careful handling and efficient curing. Ginger } \\
\text { should not be stored in used bags (potato, } \\
\text { onion etc) and the storage environment } \\
\text { should be cool, dry and well ventilated. }\end{array}$ \\
\hline $\begin{array}{l}\text { Armillaria } \\
\text { Rot }\end{array}$ & $\begin{array}{l}\text { Armillaria } \\
\text { mellea }\end{array}$ & $\begin{array}{l}\text { Development of tough, dark, } \\
\text { string-like growth which adhere } \\
\text { to the rhizomes. }\end{array}$ & Uprooting of the infested plants \\
\hline $\begin{array}{l}\text { Sclerotium } \\
\text { Rot }\end{array}$ & $\begin{array}{l}\text { Sclerotium } \\
\text { rolfsii- soil } \\
\text { borne fungus }\end{array}$ & $\begin{array}{l}\text { Small spherical fungal resting } \\
\text { bodies about } 1-2 \mathrm{~mm}(0.04 \text { inch } \\
\text { to } 0.08 \text { inch) in diameter develop } \\
\text { on the mould. They are initially } \\
\text { white but later turn brown. }\end{array}$ & $\begin{array}{l}\text { Benomyl }(750 \mathrm{ppm}) \text { or gibberellic acid (150 } \\
\text { ppm) or } 0.3 \% \text { Ridomil MZ. Steeping of } \\
\text { rhizomes in carbendazim }(0.1 \%) \text { for } 60 \\
\text { minutes (Sharma and Dohroo } 1991)\end{array}$ \\
\hline
\end{tabular}

